\title{
Taking Criticism as an Example to Explore the Development Path of Modern Chinese Painting in the Dualistic Framework of Chinese and Western Culture
}

\author{
Yifan $\mathrm{Du}^{1, *}$ \\ ${ }^{1}$ Modern College of Northwest University, Xi'an, Shaanxi, China \\ *Corresponding author. Email: $952173411 @ q q . c o m$
}

\begin{abstract}
Criticism is a questioning attitude towards things. It is a retrospective reflection based on rational logical reasoning. Western art has been critical in content and form for a long time. Since the Renaissance, it has been used as a weapon for the struggle of the bourgeoisie, and it is used to criticize the church and imperial power. Until modern times, the exploration of forms in modern Western painting is based on criticizing the predecessors, continuing to innovate and achieving achievements. Modern China was influenced by Western art, and Chinese traditional paintings, which were mainly inherited, also began to show criticality. In order to discuss the possibility of critical integration into the future development of Chinese traditional painting under the Western scientific system, this article will focus on the critical aspect of painting, taking modern Chinese traditional painting as the research object, combing through vertical development, comparing it horizontally with the critical development of Western painting, and analyzing its characteristics and the reasons behind them in order to provide theoretical support and suggestions for the critical development of Chinese traditional painting in the future.
\end{abstract}

Keywords: The dualistic frame of Chinese and Western culture, Modern traditional Chinese painting, Criticality, Social changes.

\section{INTRODUCTION}

Criticism is a questioning attitude towards things, it is a retrospective reflection based on rational logical reasoning, and it is full of discernment and judgment. Criticism originated in ancient Greece. Socrates explained some philosophical concepts through questions, queries, and debates. Criticism is a link deeply embedded in the genes of Western culture. Plato put forward the concept of the world of ideas. He believed that this world was perfect, and the current world is an imitation of it. Since it is an imitation, there are many imperfections in the current world. Westerners believe that nature is flawed and that humans are born with original sin. Therefore, they use this perfect world of ideas to rationally criticize and transform the world they live in throughout their lives. However, this situation is completely different in China. The three schools of Confucianism, Buddhism, and Taoism in traditional Chinese culture emphasize the harmony between man and nature. In the Chinese cultural system, there is no so-called world of ideas. The world is originally in chaos, everything is born in it. Out of Tao, one is born; out of one, two; out of two, three; out of three, the created universe. The Chinese believe that suffering comes from separation. If people want to eliminate suffering, they must return to the state of harmony between man and nature. Chinese culture for thousands of years is to eliminate the pain in people's hearts and realize the care for life and emotions. Therefore, it can be seen here that the term criticism doesn't exist under the traditional Chinese cultural system. It was not until the introduction of modern Western culture that concepts such as criticism, reason, and logic entered China. 
As everyone knows, in the first half of the 20th century, Chinese painting began to decline. In response to this situation, painters have used their own methods to carry out cultural renaissance. Among them, the most distinctive approach to the modern transformation of Chinese painting is the integration of Chinese and Western art and traditionalism. [1] Criticism, as the essential content of Western culture, is introduced into the modernization reform of Chinese painting. Some painters who advocated the fusion of Chinese and Western began to try to add rational criticism to painting creation, and Mr. Li Keran was one of them. In "Talking About the Transformation of Chinese Painting", he said: "If we want to transform Chinese painting, we must first use progressive scientific methods to criticize and study heritage. We must try our best to accept the valuable and useful experience of our ancestors, absorb the useful elements of foreign art, and establish a sound and progressive new realism." [2] Western rationalist science is very advanced, and it is very necessary for Chinese people to use Western advanced scientific methods to examine, criticize, and then transform their own Chinese paintings. Other researchers who advocated traditionalism believed that the development of Chinese painting must be based on the preservation of excellent genes, and couldn't develop in the direction of "transgene", which was the best choice to respect the laws of art. [3] Although the two perspectives of Chinese and Western fusion and adherence to tradition are fiercely confronting, it is difficult to focus on the arguments. These arguments usually talk to themselves and find suitable rationales for debate, but it is difficult to refute the other side's point of view. Therefore, the author focuses on the representative of Western rational philosophy criticism, and sorts out and reflects on the issues of whether Chinese painting should learn from criticism, and what the development situation after learning from criticism is.

This article takes modern Chinese paintings as the research object, takes the criticism expressed in the paintings as the breakthrough point, and uses the literature research method and case research method to interpret and explore the transplantation condition of Western rational criticism in modern Chinese painting from the two dimensions of the dual cultural background of China and the West and the vertical change of society, being intended to learn from experience, learn lessons, and provide theoretical support and practical suggestions for the future development of criticism.

\section{THE DEVELOPMENT OF WESTERN CLASSICAL PAINTING IS A CRITICAL DEVELOPMENT}

\subsection{Criticizing Medieval Theology and Rooting for the Bourgeoisie}

The Western Renaissance Movement is an artistic and cultural movement that reflects the demands of the emerging bourgeoisie, opposes divinity, and liberates humanity. With the continuous growth of the bourgeoisie, Western countries have launched bourgeois revolutions, liberated the productive forces, and embarked on the road of capitalism. As a weapon of political propaganda, art is raising the flag for the bourgeoisie, and at the same time, it has developed and matured under the capitalist system. During the Renaissance, people promoted human nature and opposed divinity, and the theme of painting changed from religious themes to express the people in reality, revealing the corruption of the church and criticizing feudal society. Velazquez created "Pope Innocent X", which truly reflected the cruel and greed of the Pope. In the 17th and 18th centuries, three major bourgeois revolutions broke out in the Western world, which included the English Bourgeois Revolution led by Cromwell, signing the Bill of Rights, which established the constitutional monarchy and restricted the rights of the king; the French Revolution led by Robespierre, issuing the "Declaration of the Rights of Man and of the Citizen" and ending the feudal despotism in France; the American Revolution led by Washington, overthrowing the British colonial rule, promulgating the "Declaration of Independence" and establishing the United States of America. In order to bang the drum for the three bourgeois revolutions respectively, William Hogarth created "Fashionable Marriage" to reveal the corruption of the British aristocracy and promote the process of democracy; David created "The Death of Marat" and Delacroix created "La Liberté guidant le peuple" to help the French Revolution; Benjamin West also witnessed the American Revolution with his paintbrush. It can be said that the development of Western painting is closely related to the development of capitalism. Western capitalism has developed for many years. Until nearly 1920s, some irreconcilable contradictions under capitalism began to appear more and more frequently, and more and more people began to reflect on this social system. Therefore, some trends of criticism and reflection on capitalism's own system are also 
manifested in the field of art. Whether it is Western modern formalism or post-modernism, both contain significant criticism. [4]

With the development of capitalism and the growth of the bourgeoisie, especially after the Industrial Revolution in Great Britain, the rapid development of science and technology has made people more and more believe in their own power, and they have begun to break away from the shackles of theology and the church. Rationality and science are gradually established in society as a kind of ideological weapon of the bourgeoisie. The painting field also actively responds to the rationality and science advocated by the bourgeoisie. The infusion of science and technology has led to the innovation of many painting forms and the emergence of many modernist schools. For example, the theory of light and shadow gave birth to impressionism, and the decomposition of three primary colors gave birth to pointillism, and so on. Conversely, the successful practice of these sciences and technologies in the field of art is also the cheer of art to the bourgeoisie.

\subsection{Criticizing the Aristocracy and Speaking for the Lower Class}

Contemporary Western painting is greatly influenced by Western philosophy. It is well-known that a characteristic of Western modern painting schools is that each school is an exploration of art form based on a concept. From Kant and Hegel to Heidegger and Marx, modern Western philosophy is a rational and critical dialectical philosophy. Reflected in the art of painting, this kind of speculative ability is the reflection on the content and criticism of the form. It is the application of this critical thinking that enables the rapid development of modern Western painting and reveals its vitality.

The content of classical and academic paintings is mainly biblical stories, major historical events, or descriptions of the lives of royal nobles. There are strict regulations on the form, and the position and posture of the characters are drawn in accordance with the rules. For example, "The League of the Brothers of Horace" drawn by the neoclassical painter David shows perfect composition, superb painting techniques and arrangement of scenes and characters. But these noble academic paintings seemed to be very divorced from reality in the eyes of some middle-class and speculative young painters. One of the painters who held this idea was
Courbet. In 1855, he created "A Burial at Ornans" and "The Studio" to take part in an exhibition, but they were rejected by the panel. Out of anger, he provocatively set up a shed on the opposite side of the expo, and held an exhibition of his own, which was called "Realism, 40 Works by Courbet". He harangued about his artistic ideas, criticized the "noble subjects" advocated by conservatives, pointed out that realism was the art of the people and it needed to reflect the real life, and emphasized the great significance of reflecting the lives of civilians. Courbet tirelessly portrayed poverty scenes. In fact, this had a lot to do with his early experience of participating in the French Revolution. His masterpiece "The Quarrymen" depicts the difficult life of the lower-class quarrymen. In the mid-19th century, French society was very polarized, the gap between the rich and the poor was very large, and the nobility was corrupt. Realist artists such as Courbet used paintbrushes to assume social responsibilities, depicting the luxury of the noble class and the hardships of the realistic lower-class people, reflecting and criticizing this social phenomenon of extreme disparity between the rich and the poor, and expressing sympathy for the lower-class people and hatred for the noble class.

Beginning with impressionism, painters consciously captured the momentary changes in light and shadow, recorded the momentary dynamics of the characters, and even showed pictures of the characters showing only half of their faces - this didn't conform to the regulation in the classical academic painting system seriously. The characters were no longer dignified and flawless, and casually dressed citizens replaced the royal court's perfect nobles. For example, Degas's "Cotton Purchase Office", "Horse Race", and "Ballerinas" all targeted the lower-class people and emphasized capturing the moments of daily life. This new feature of impressionism was precisely the painter's reflection and criticism of the "noble content" and "ideal form" that the previous academics insisted on.

\subsection{Criticizing Academic Authority and Fighting for Artistic Freedom}

In the 19th century, Paris, France, was the center of Western art. The academism occupied an absolute position, controlling the admission ticket to the official salon. The young and middle-aged painters with innovative spirit were rejected by the conservative academism. Their works couldn't enter 
the official salon and could only be exhibited in the salon of the also-ran, causing great resentment among the young painters. These young painters criticized the academic rules of "noble subject matter", "balanced composition" and "correct sketch". They demanded innovation in artistic techniques and concepts, and fought for the right to freely create, so they often gathered together to criticize academic art and find the direction of artistic innovation. In 1874, the young Monet created a painting depicting the sunrise and wanted to use it to participate in the official salon exhibition, but he was rejected. Then this group of defeated painters headed by Monet retrieved the paintings in angrily and held a private exhibition in an apartment not far from the official salon to show their dissatisfaction and challenge the official salon. Participants in this exhibition included modernist masters such as Monet, Renoir, Pissarro and Degas. After seeing the exhibition, Louis Leroy, a reporter from The Noise Weekly, satirized Monet's work depicting the sunrise: "This painting is a denial of beauty and reality, and it can only give people an impression." It was precisely because of this insulting report that "impressionism" got its name and Monet together with the painting "Impression Sunrise" became famous overseas. The common feature of impressionist paintings is to retain the most original brushstrokes without deliberate modification, to quickly capture the momentary changes of light and shadow and to depict ordinary scenes in life. Another leading figure of impressionism is Manet. Although he never participated in an impressionist exhibition and didn't recognize himself as an impressionist painter, he was still admired by modernist painters such as Monet, Cezanne and Van Gogh. He was the trailblazer of modern painting, and from then on, painting entered the path of pursuing the beauty of the art form itself, and was no longer bound by realistic things.

Since the emergence of impressionism, modern art has made breakthroughs and modernism has begun to sweep the entire Western art world. During the half century from the end of the 19th century to the beginning of the 20th century, the bourgeoisie stepped onto the political stage, the capitalist economy developed rapidly, the modern industrial culture was rampant, and Marx's politics and economics became the mainstream of philosophy... Against this background, a number of modern art schools such as fauvism, cubism, futurism, Dadaism, expressionism, surrealism, abstractism, and pop art appeared in sequence in
Western art. These modernist schools, including fauvism with strong colors, thick outlines, and distorted shapes of the body; expressionism that expressed subjective feelings and gave vent to emotions; cubism that used geometric elements to cut natural shapes and recombine them to express the four-dimensional space; futurism that depicted speed and strenuous exercise; Dadaism that denied everything and destroyed everything; abstractism that got rid of the tradition of artistic representation of visual feelings, and took points, lines and surfaces as painting elements, etc., were all in their own way to get rid of the shackles of tradition and fight for artistic freedom. At the same time, postmodernism was also rebelling against modernism with a critical attitude, trying to open up broader freedom.

\section{THE DEVELOPMENT OF CHINESE PAINTING IS A KIND OF INHERITED DEVELOPMENT}

Since the Song Dynasty, Chinese painting was firmly held in the hands of the literati class, and literati and officialdom of successive reigns and dynasties had the absolute right of speech in Chinese painting. However, the stubborn selfdefense of the Chinese literati class affected the breakthrough development of Chinese painting. Several changes in Chinese painting in history occurred during the invasion of foreign nations and the great integration of nations.

Confucianism, Buddhism, and Taoism have influenced China for thousands of years, especially in the literati class. Confucian culture built an ethical relationship between people, namely, letting the king be a king, the minister be a minister, the father be a father and the son be a son. Everyone has his or her own position and must not usurp. Buddhism pays attention to the emptiness of dependent origination. If the cause is there, then the object is there, if the cause disappears, then the object extinguishes. Everything is impermanent and the only thing that doesn't change is the Buddha nature. Taoist culture emphasizes that the Tao way follows nature and the harmony between man and nature. It advocates getting rid of subjective prejudices and doing everything in accordance with objective laws, and treating everything in the world equally, so as to "not be tired of external things but be free and unfettered". [5] It can be seen from this that the three schools of Confucianism, Buddhism, and Taoism didn't advocate people to criticize reality, starting from rationality and actively 
thinking of ways to fight for their own temporal interests. Instead, they put forward a series of selfexplaining ideas for releasing the pain in people's heart and provided care at the emotional level of life. Based on this kind of idea, there are almost no critical realist paintings in Chinese paintings that depict human suffering and reflect social problems. The literati paintings that occupy the mainstream of the painting world pursue the artistic interest of "scribbling a few strokes, which are not required to be very similar, but are only used for entertainment and expressing detached spirit and bearing". [6] The themes of bird-and-flower paintings are mostly plum blossoms, orchid, bamboo, chrysanthemum, golden pheasant, and peacock, which are used to express the master's virtue or family wealth; landscape paintings don't describe real scenes, but are mostly ideal places for painters to become immortal; the themes of figure paintings are mostly emperors, martyrs and Confucian scholars of the past dynasties, which are used for introspection and self-examination of viewers.

Not only was the development of ancient Chinese painting mainly through inheritance, but also in modern times after the introduction of Western rational criticism into China, inheritance is also the primary way to learn Chinese painting. In modern times, Mr. Li Keran mentioned in "Tradition, Life and Others": "From the perspective of Chinese cultural history, Chinese people are very aspiring and have never rejected foreign culture. But there is a very important point, that is, we must inherit the tradition, we must put Chinese tradition first and foreign things must be put in the second place. National traditions are a matter of inheritance. Foreign cultures can only be absorbed as nourishment for the purpose of enriching and developing our own traditions. The master-slave relation must be clear." [7] This sentence makes it very clear that inheritance is the purpose of transforming traditional Chinese painting, and absorbing foreign culture is only one of the means, not the purpose.

The importance of inheritance is self-evident in China. Mr. Zhang Daqian said: "Learning from tradition is extremely important. China has a long tradition of painting and art, and there are many famous relics left by masters in the past dynasties. They spent a lifetime and accumulated a lot of experience in different societies. We should learn from these rich experiences, and then use them in artistic practice, develop them, and gradually form our own styles. This is a lifelong matter, and it won't work without hard work."[8] Without learning from tradition, there is no way to talk about inheritance. Mr. Zhang Daqian visited Dunhuang twice in the era of flames of war in order to copy the murals of Mogao Grottoes. When copying, he was completely faithful to the original, and strived to accurately restore the image and text of each mural. According to legend, when drawing in the cave, due to the dim light and small space, he often had to hold a candle in one hand and draw with the other hand, and even climb up and down, or squat, or lie down, often being dizzy. Mr. Zhang Daqian often drew all day and sometimes stayed up late. It can be seen that the status of inheriting tradition is very high among Chinese painters, since the master studied tradition so hard.

Regarding how to inherit and learn traditional culture, Mr. Guan Shanyue put forward the concept of "生". He said: "In traditional painting theories, from the initially mentioned '写真 (describing something as it is)' to '写生 (painting from life)', from '览之若面 (seeing it is like seeing one's face)' to '气韵生动 (possessing lively spirit and charm)', all of them attach importance to the word '生', which is a higher artistic requirement for objective modeling such as vivid expressions and typical postures of object images, as well as the author's living personality and temperament and artistic style. Ignoring these and focusing only on the extreme resemblance in form and color can only portray vivid objects as stiff dead objects." [9] The "生" here means that people should combine their own thoughts, emotions, attitudes and other factors while learning traditional painting styles to inject spirit into the pictures. Compared with mechanical inheritance, this is a higher level of dynamic inheritance.

It can be seen that even after witnessing the "powerfulness" of the West and the "backwardness" of China in the first half of the 20th century, the two modern masters of Chinese painting, Mr. Zhang Daqian and Mr. Guan Shanyue, still insisted on borrowing from the past and opening up the present, promoting the modernization reform of Chinese painting in the inheritance. The author believes that the reason is that China has been a self-sufficient feudal society since ancient times. The family is the smallest unit of the society, and the parents are the teachers of their children. In the era when there is no universal comsulsory education for the whole people, the knowledge of children is completely inherited from their parents. The knowledge is inherited from top to bottom from generation to generation, forming an 
extremely stable closed loop. The calligraphy-sage Wang Xizhi of the Eastern Jin Dynasty was born in the Langya Wang family. This family was very famous. From the Eastern Han Dynasty to the Ming and Qing Dynasties, 92 prime ministers and more than 600 literati and famous officials were cultivated. Wang Xianzhi, son of Wang Xizhi, was also a master of calligraphy and painting. Su Shi and $\mathrm{Su} \mathrm{Zhe}$ were also the sons of $\mathrm{Su}$ Xun of the $\mathrm{Su}$ family from Meishan. In addition, there was also the Zeng Guofan family, which had produced more than 240 outstanding talents without any black sheep in the past 200 years. Western society, by contrast, was built on a social contract. From birth, people went to church for baptism and became God's people. At this time, the relationship between children and their parents was no longer a parentchild relationship, but conversus. They are all God's people and are equal. This kind of social foundation led to a strong sense of self-consciousness and critical consciousness of citizens, which was completely different from China's traditional culture of inheritance.

\section{THE ATTEMPT OF MODERN CHINESE PAINTING TO TAKE A CRITICAL DEVELOPMENT PATH}

\subsection{Opposing Feudal Regime and Shouting for Science and Democracy}

As China's last feudal dynasty, the Qing Dynasty, became decayed, the Chinese nation, faced with Western ships, armaments, flames of wars and smokes of gunpower, deeply felt that it was about to be beaten up if it was backward. At the beginning of the 20th century, Chinese people with lofty ideals took action one after another. In the process of anti-feudalism and overthrowing the Qing Dynasty, they advocated the study of advanced Western scientific knowledge and democratic ideas. Painters of the older generation such as $\mathrm{Xu}$ Beihong and Jiang Zhaohe began to criticize feudal society and foreign invaders with their own brushes. They internally reflected on the drawbacks of the country and society, showed their deep sympathy for the poor common people, enlightened people's thought, and called on everyone to unite, externally, they absorbed the advanced science, culture and technology of the West and spread it in China, while criticizing the aggression of the foreign powers. At this time, patriotic painters mostly depicted works embodying national character and popularity.
Mr. Wu Guanzhong agreed that pen and ink should follow the times. He once said: "The reason why I am who I am is naturally because that there is value for my existence. The beards and eyebrows of the ancients can't grow on my face; the viscera of the ancients can't enter my intestine." [10] Everyone's growth can't be separated from the times and can't be separated from the destiny of the country and the nation. At the moment when the nation was invaded and the country was in danger, every painter should have the responsibility to make far-reaching planning for the future of the nation-state, save the nation from subjugation and ensure its survival, comment on current events, and contribute his own strength. If one blindly returned to the ancients and worked behind closed doors at this time, one would fall to the situation of being neither fish nor fowl.

Chinese painters actively studied Western academism of painting, and introduced scientific methods of Western painting such as scenography, chiaroscuro, color, and ratio method into China. The most famous was painting from life proposed by $\mathrm{Mr}$. $\mathrm{Xu}$ Beihong, which used scientific observation, analysis and expression methods to carry out the creation of Chinese paintings. Thanks to the advocacy of $\mathrm{Mr}$. Xu Beihong, painting from life began to occupy a major position in the Chinese painting circle in the 1920s. "Painting from life of Chinese landscape painting has its own characteristics, which is different from painting from life of landscape in Western painting. Painting from life of Chinese landscape painting not only attaches importance to the selection and description of objective scenery, but also pays attention to the recognition and reflection of subjective thinking on the scenery, emphasizing the role of the author's thoughts and feelings. In the entire process of painting from life of landscape painting, it is necessary to implement the requirement of a fusion of feelings with the natural setting. The author reflects his own thoughts and feelings through the description of the scenery. First of all, he must choose the scenery for painting from life. Only being in line with one's own taste can the sight stir up one's feelings." [11] Painting from life can't indiscriminately imitate Western methods, but must have its own characteristics, that is, the participation of subjective thought. This argument shows that while studying Western scientific methods and criticizing own traditions, the Chinese take a selective and rational view of the science promoted by Western art. 


\subsection{Opposing Imperialist Aggression and Contributing to National Independence}

When the September 18th Incident broke out in 1931, the Japanese imperialists invaded China by force. China was facing an unprecedented national crisis of genocide. The Kuomintang and the Communist Party and the people of the country united as never before to resist foreign aggression. At the moment of national peril, patriotic people with lofty ideals actively participated in the antiJapanese and national salvation movement. At this time, Mr. Xu Beihong created "Jiu Fang Gao". The painting depicted the story that Jiu Fanggao was not confused by appearances, instead, he saw the essence of things, and recognized the swift horse at a glance. This work expressed the author's dissatisfaction and criticism of those in power who used appearances to judge, appointed villains, didn't know talents, and couldn't appoint people on their merits when the country needed hands; in addition, it also expressed the author's praise for the simple working people of spirit.

The Lugou Bridge Incident broke out in July 1937, which opened the prelude to the Comprehensive Anti- Japanese War. Japan attempted to destroy China in three months, and Chinese center stage battlefield was defeated steadily, and large tracts of territory in North and Central China were lost. At this time, Mr. Xu Beihong successively created works such as "Fowls Crow in the Wind and Rain", and "Ba People Draw Water" in 1937. "Fowls Crow in the Wind and Rain" depicted a big rooster standing upright on the rock despite the wind and rain, showing the author's firm will to fight against the war. "Ba People Draw Water" depicted the daily situation of the working people in the mountain city of Chongqing fetching water, and showed the author's praise for the struggling spirit. Through this painting, he called on the people of the whole country to fight to the end without fear of hardship.

Around 1940, the War of Resistance against Japanese Aggression was in a stage of strategic stalemate. Japan had already occupied more than half of China. Japan, due to its own lack of human and financial resources, changed its strategy and adopted the aggressive policy of politically luring the Kuomintang into surrender and the main attack on the Communist base areas behind enemy's rear area. So the army and the people in the antiJapanese base areas began an arduous struggle. During this period, Mr. Xu Beihong completed Chinese paintings such as "The Foolish Old Man
Who Removes the Mountains", "Against the Wind", "Herds of Horses", "The Spirit Vulture" and other works. The large face of the foolish old man family in "The Foolish Old Man Who Removes the Mountains", the sparrows fighting against the wind in "Against the Wind", the majestic and galloping horses in "Herds of Horses", and the high-tempered vulture standing on the rocks in "The Spirit Vulture" were all painted by the author in order to encourage the army and the people in the base areas behind enemy's rear area to work hard, persevere in the struggle, and fight to the end.

At a time of national peril, Chinese painters used their paintbrushes to inspire the people of the whole country to unite and resist aggression. In the face of changes in the war situation, Chinese painters also used paintbrushes to express their thinking about the current situation and contributed their wisdom. As the saying goes, of the nation, of the world. Patriotism stirred in painters' chests, prompting painters to pick up paintbrushes again and again to work hard for the victory of the war of resistance in the rapid flow of national destiny, and at the same time to draw an evocative picture of national history.

\subsection{Opposing the Landlord Class and Serving the People}

Old man Qi Baishi is most famous for "The Sound of Frogs Miles Out of the Mountain Spring". There is the sound of frogs in the title of this painting, but there is no frog in the picture. There are only a few tadpoles, floating down the stream. The design is ingenious and makes people smile. "Ink Shrimp" is also a famous painting by the old man Qi Baishi. These crystal clear shrimps with different postures seem to move in the water. "I Know the Fish Best" depicts a situation where a group of fish gather to bite the hook. A fishing line hangs straight down and the picture is neat and tidy. "Chicks" depicts a group of chubby chicks chasing and pecking, which is very cute. "Weighing Oneself" depicts a little fat mouse lying on the hook of the steelyard, making people can't help laughing... These paintings all have a simple and rustic taste, which reminds people of a simple childhood and lovely fellow countrymen. The old man Qi Baishi is especially loved by the people because he took Chinese paintings from the altar, to the streets and alleys, under the trees in the village, and to the working people. His paintings are full of the fun of life and the warm love for life, making people can't help laughing. His paintings were for 
simple laborers, so in 1953, the Chinese Ministry of Culture awarded him the title of Outstanding People's Artist.

The northwest region was rarely involved in Chinese literati paintings before. After the founding of New China, the vast number of laborers opened up wasteland and built their homes in the northwest region. Facing the vast expanse of the vast northwest of the motherland and the unpredictable natural forces, people deeply feel their insignificance and awe of nature. At the same time, they are not afraid of hardships and work hard to create a happy life. They deserve to be eulogized. Here, four painters went deep into the hinterland of the northwestern China, working tirelessly to record these brave and lovely laborers and their lives.

The first one was Mr. Zhao Wangyun. From the 1940 s to the 1950s, Mr. Zhao Wangyun, as the founder of the "Chang'an Painting School", put forward slogans such as "popular art", "artists should step out of the ivory tower and move forwards the streets", "go to the folk", and "go to the people". Mr. Zhao Wangyun once said that "all happiness is obtained through hard work, and the beauty of the scenery is mostly due to human activities". [12] Mr. Zhao Wangyun created many pictures of the working lives of farmers, workers, and people of various ethnic minorities. He mostly depicted life in fields, grasslands outside the Great Wall, Qilian Mountain, gobi desert, and Northwest Plateau... He didn't crow about the rich in his life, but only painted for the masses of the hardworking people in the northwest.

The second was Mr. Shi Lu, who was one of the leading figures in the painting circle from the 1960s to the 1970s. He was most famous for "Fighting in Northern Shaanxi", "On the Way to Nanniwan" and so on. Mr. Shi Lu said: "The minerals of life are in the hearts of the people, and there is no other way to explore and mine, but to feel for others... The subject of life is people. Observe and understand people's emotions in order to analogize everything." [13] It can be seen from Mr. Shi Lu's words that his paintings were made for the people, with the people as the center, and his class stand was very firm.

Mr. Liu Wenxi, the founder of the "Loess Painting School", also painted to praise the diligent and simple working people on the Loess Plateau in northern Shaanxi. His most famous "Four Generations of Grandparents and Grandchildren" depicted the portraits of the grandparents and grandchildren of the working people in northern Shaanxi together. In addition, the paintings depicting Chairman Mao's life in northern Shaanxi, such as "Chairman Mao and the Shepherd", "The East", "The Sky in the Liberated Area" and "The Loess People" all showed love for the working people in northern Shaanxi. Mr. Liu Wenxi worked tirelessly. He personally went to northern Shaanxi more than 90 times to collect folklore, and spent the New Year with fellow villagers in northern Shaanxi 17 times. He established a deep relationship with the people in the old revolutionary base areas, and devoted his life to creating works that praise the working people in northern Shaanxi.

The fourth was Mr. Huang Zhou. He always followed "life is the only source of creation" on the road of art. He was deeply involved in life for a long time, and his footprints spread all over the country. He believed that "good works need the approval of the masses. Don't raise yourself too much. Art must include life. Formalism has no way out." [14] The words "the approval of the masses" explain the starting point and destination of Mr. Huang Zhou's paintings.

This kind of eulogy to the general working people is a reflection and critical attempt by Chinese painters in terms of content that only focused on the expression of personal inner feelings. It can be said that these attempts are very successful.

\subsection{Opposing Centralization and Supporting Artistic Diversity}

After the end of the 10-year Cultural Revolution, marked by the Third Plenary Session of the 11th Central Committee of the Chinese Communist Party, China began its reform and opening-up centered on economic construction. A large number of Western books have been translated into Chinese and introduced into China, and new Western art concepts have also poured in. These Western thoughts have greatly influenced Chinese young and middle-aged artists, and they begin to apply these thoughts to artistic creation. In 1985, there were two important events in the development of Chinese contemporary art: one was the "85 Fashionable Art" with the second Western learning translation heat as the background, and the other was a big discussion on Chinese painting. These two events had a huge impact. They liberated people's minds in terms of artistic language and new artistic concepts, and opened the way for artistic freedom and the diversified development of art. 
With the increasing frequency of art exchanges between China and foreign countries, artists from various countries visit each other to learn, exchange skills, go abroad for further studies, hold exhibitions, participate in conferences, etc., and Chinese people have a comprehensive and rapid understanding of the state of Western art and culture. Chinese painters pay more and more attention to the expression of artistic individuality and the pursuit of artistic freedom. The works of young and middle-aged artists often show critical and philosophical meaning, and their formal styles often show diversity. Self-consciousness makes the modernization exploration of Chinese painting present a diversified trend. The content of Chinese painters' performances is constantly expanding. In addition to landscapes, flowers and birds, and figures, postmodernism with "subversion and rebellion" as the core is also added.

Since the reform and opening up, China has implemented a socialist market economic system with economic construction as the center. In order to maximize economic benefits in the market, people must use innovation as a driving force and take evolving to change as a method. The baton of the economic market is handed over to the law of value, and the government's macro-control is only used as an aid. Under this circumstance, the economic way of decentralized self-financing makes a great clamor. Undoubtedly, Chinese painting has also entered the market circulation domain as a commodity. The new characteristics of decentralization, individualism and diversification in the market also act on the creation of Chinese paintings.

Mr. Pan Tianshou said in "Talking About the Characteristics of Chinese Traditional Paintings" in 1957: "The paintings of the two major systems of the East and the West each have their own highest achievements. They are like two great peaks, facing each other between the two continents of Europe and Asia, making the whole world 'extremely admire'. Between the two, they can draw on each other's strengths so as to increase the height and width of the two peaks, which is very necessary. However, they can't absorb casually... Otherwise, instead of increasing the height and width of the two peaks, they may subtract their own height and width, flatten themselves and lose their unique style." [15] This sentence first affirms that art must be different and can learn from each other, but it can't be forced. With the increasingly frequent exchanges between China and the West and the acceleration of the process of globalization, people share a global village, facing increasingly similar problems, living under similar technologies and cultures, but using different means to solve nearly the same human problems. No one is better than the other, because people have the same destination, and like technology and culture, art is interlinked in the end.

\section{CONCLUSION}

In summary, the author summarizes the conclusions as follows:

To begin with, criticism in Chinese paintings is unique in modern times, and is a product of Western art and culture. Criticism has its incompatibility under the framework of Chinese art and culture. The main reason is that traditional Chinese art emphasizes the expression of "meaning", which is a eulogy to life and emotion, while Western criticism is the behavioral approach of a rational level, mainly involving concepts, reasoning and other content. It can be seen that the focus of Chinese and Western art is different.

Next, as for the situation that criticism is not acclimatized after it is introduced into modern Chinese painting, the main reason is that it has too much direct conflict with the mainstream of Chinese traditional culture - Confucianism, Buddhism, and Taoism. Chinese philosophy emphasizes the harmony between man and nature, and doesn't regard man and nature as two opposite aspects. However, Western philosophy has opposed man and nature since the beginning of Greek philosophy, and regarded nature as the object of transformation. Criticism, as a means of transforming nature, occupies a certain position in Western society, but for China, which emphasizes the harmony between man and nature, criticism is not a mainstream means.

In the end, in view of the above discussion, the author believes that criticism in the current environment has a lot of successful attempts, but there is still much maladjustment, which shouldn't be forced. In the long river of history, criticism is indeed an imported product in China, just as "the harmony between man and nature" is indeed difficult to be understood in the West. For two equally long and strong cultures, letting go of prejudice and respecting each other instead of antagonizing the two is the best way to deal with them. 


\section{AUTHORS' CONTRIBUTIONS} Du.

This paper is independently completed by Yifan

\section{REFERENCES}

[1] Hu Yun. The formation of two major approaches to the modern transformation of Chinese painting - a study on the controversy of Chinese painting in the first half of the 20th century [J]. Art Education Research, 2015(17): 69. (in Chinese)

[2] Li Keran. Li Keran on Chinese painting (1) [J]. Education Journal for Senior Citizens (Art of Calligraphy and Painting), 2010, (10): 3233. (in Chinese)

[3] Cheng Dali, Ya Lijuan. The development of Chinese painting can't be "transgenic" [J]. Century, 2018(01):41-43. (in Chinese)

[4] Zhang Jian. Art criticism and social cultural criticism - a tendency of Western modern and contemporary art criticism [J]. Art Observation, 1998(09):56-59. (in Chinese)

[5] Gao Liangzhi. On Chinese philosophy [M]. Wuhan University Press, 2014. (in Chinese)

[6] Yang Wei. Facing reality and exploring in depth - about Liu Xiangdong and his paintings [J]. Fine Arts, 2017(4). (in Chinese)

[7] Li Keran. Tradition, Life and others - a conversation with ten middle-aged and young landscape painters in the "Picturesque Rivers and Mountains" Exhibition [J]. Literature and Art Studies, 1982(02):118-121. (in Chinese)

[8] Liu Dehui. The influence of Zhang Daqian's adherence to and innovation of Chinese painting traditions during his overseas period [J]. Beauty \& Times (Part 2), 2017, 710(07):61-63. (in Chinese)

[9] Wang Shanmin. The image traces are completely unified, and the meaning is born from the heart - distinguishing the exploration of Chinese painting from life [J]. Art Education, 2007, 000(008):114-115. (in Chinese)

[10] Wu Guanzhong. My reading of Shi Tao's painting quotations $[\mathrm{M}]$. Shandong Pictorial Publishing House, 2009. (in Chinese)
[11] Fu Baoshi. The painting from life of landscape painting pays more attention to the spiritual level [J]. Appreciation, 2019, 000(003):168168. (in Chinese)

[12] Fan Minjie. Analysis of the performance of northern Shaanxi dwellings in landscape paintings [D].

[13] Zhao Qibin, the photo library of this magazine. The common and different reasons for the formation of Shi Lu's and Fu Baoshi's painting thoughts $[\mathrm{J}]$. Appreciation, 2020(07):56-64. (in Chinese)

[14] Ding Shuzhe. Life is the source of creation the second Huang Zhou teacher-student painting exhibition opened at Yan-Huang Art Museum [J]. Fine Arts, 2011, 000(006): 7. (in Chinese)

[15] Xu Jiang. Standing on the highest peak and singing the east of the great river [J]. Fine Arts, 2017, 594(06):50-54. (in Chinese) 